\title{
Pengembangan Media Pembelajaran Matematika Berbantu Adobe Flash Melalui Etnomatematika pada Rumah Adat Lampung
}

\author{
Resty Khairina Vevi M. P1, Dona Dinda Pratiwi², Mohammad Muhassin ${ }^{3}$
}

1), 2), 3) Universitas Islam Negeri Raden Intan Lampung, Indonesia

Correspondence: $\mathbb{M}$ restykhairina95@gmail.com

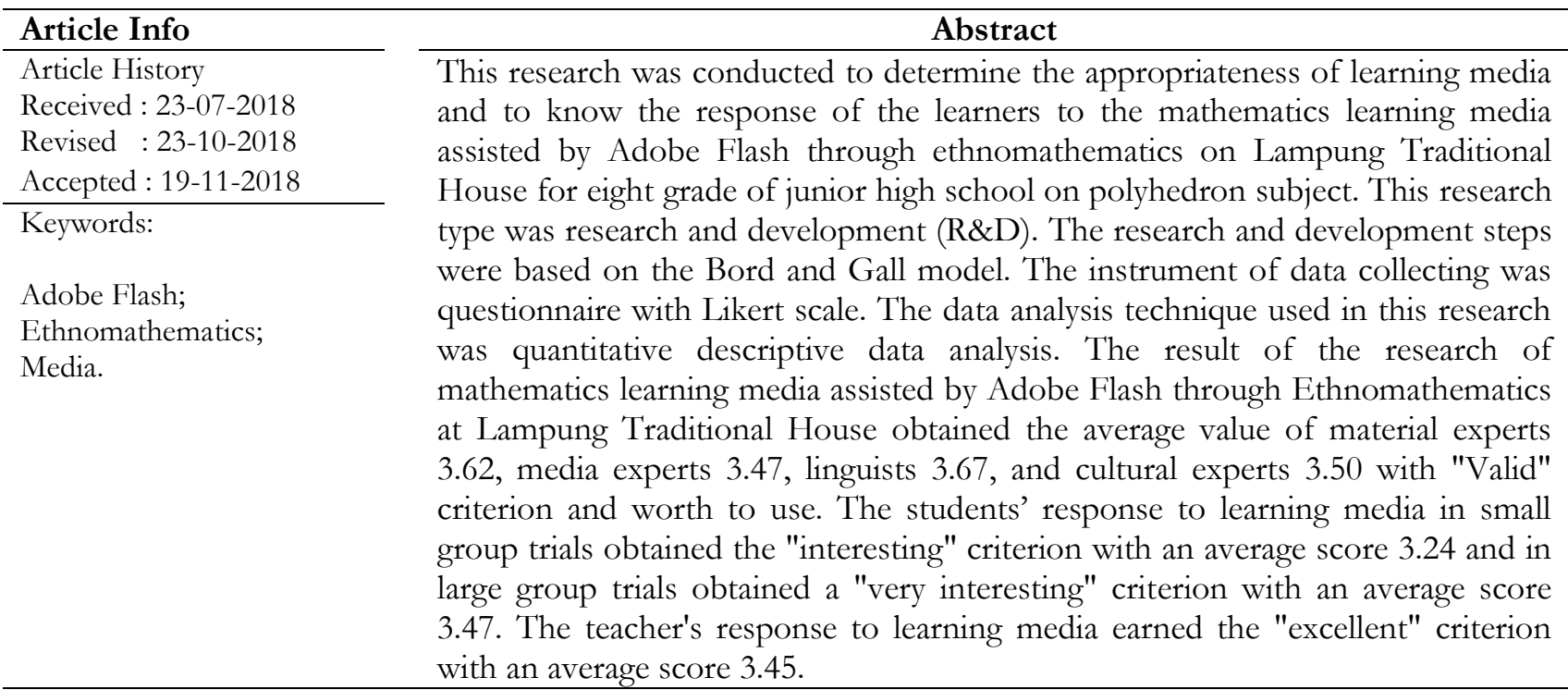

\section{PENDAHULUAN}

Pendidikan merupakan salah satu bagian penting dalam kehidupan manusia yang akan dibutuhkan sampai akhir hayatnya karena pendidikan membuat manusia berusaha mengembangkan dirinya sehingga mampu menghadapi setiap perubahan yang terjadi di kehidupannya[1]. Bidang studi yang menduduki peranan penting dalam pendidikan yaitu matematika. Setidaknya hal itu bisa terlihat dari jam mata pelajaran matematika disekolah yang mendapatporsi lebih banyak dibanding pelajaran lainnya. Matematika juga termasuk mata pelajaran yang menjadi standar untuk diujikan ketika akan melanjutkan kejenjang pendidikan yang lebih tinggi. Sehingga matematika dapat dikatakan merupakan ilmu yang sangat berperan penting dalam kehidupan [2]. Matematika adalah disiplin ilmu yang telah dipelajari semenjak pendidikan dasar dan membantu perkembangan disiplin ilmu lain seperti fisika, kimia, biologi, ekomomi dan lainya. Dalam perkembangannya, banyak konsep matematika diperlukan untuk membantu menyelesaikan masalah dalam kehidupan sehari-hari yang dihadapi, seperti halnya untuk membantu manusia dalam memahami dan menguasai permasalahan sosial, ekonomi, dan alam. Dalam belajar metematika seseorang dilatih untuk berpikir kreatif, kritis, jujur dan dapat mengaplikasikan ilmu matematika dalam menyelesaikan suatu permasalahan dalam kehidupan seharihari maupun dalam disiplin ilmu lainnya[3].

Hasil survei TIMMS (Trend in Internasional Mathematics and Science Study) pada tahun 2015 melaporkan bahwa Indonesia menduduki ranking ke-45 dari 50 negara untuk skor matematika. Secara umum disemua aspek konten maupun kognitif, baik untuk matematika maupun sains. Selain hal tersebut secara internal 66\% siswa Indonesia mengaku sangat menyukai dan merasa enjoy dengan pelajaran matematika. Jumlah ini lebih besar dibandingkan rerata Internasional 45\%. Namun ketika 
siswa diminta untuk menjawab pertanyaan menganai kepercayaan diri terhadap kemampuan matematika yang dimilikinya hanya 23\% siswa Indonesia yang percaya diri. Presentase ini relative rendah dibandingkan negara-negara lainya [4].

Seiring dengan perkembangan zaman yang semakin modern ditandai dengan berkembangnya teknologi diharapkan seorang pendidik dapat mengoptimalkan proses pembelajaran khususnya penggunaan media pembelajaran. Pemakaian media pembelajaran dalam proses belajar mengajar dapat membangkitkan keinginan dan minat yang baru, membangkitkan motivasi dan rangsangan kegiatan belajar, dan bahkan membawa pengaruh-pengaruh psikologis terhadap siswa. Penggunaan media pembelajaran pada tahap orientasi pembelajaran akan sangat membantu keefektifan proses pembelajaran dan penyampaian pesan dan isi pelajaran pada saat itu. Selain membangkitkan motivasi dan minat siswa, media pembelajaran juga dapat membantu siswa meningkatkan pemahaman, menyajikan data dengan menarik dan terpercaya, memudahkan penafsiran data, dan memadatkan informasi [5]. Oleh karena itu media pembelajaran sangat dibutuhkan dalam dunia pendidikan saat ini karena dapat memudahkan guru dalam menyampaikan informasi dan memudahkan peserta didik dalam menerima informasi.

Sumardyono dalam Chandra menyebutkan bahwa obyek-obyek matematika memiliki sifat sosiokultural-histroris. Betapapun primitifnya suatu masyarakat, matematika adalah bagian dari kebudayaannya. Matematika dan pembelajarannya menjadikan matematika milik seluruh umat manusia, dan karenanya matematika bersifat universal. Matematika bahkan lahir dari perjalanan panjang yang menyejarah dalam kehidupan manusia. Uraian ini menyiratkan bahwa matematika lahir berdasarkan sejarah, memiliki sifat reinvention atau pengetahuan yang dapat ditemukan kembali dengan cara memahami atau mengikuti bagaimana cara pengetahuan itu ditemukan, hal yang seharusnya dapat siswa alami dalam pembelajaran matematika. Selain itu, matematika yang merupakan bagian dari kebudayaan setiap kelompok masyarakat, membuka peluang digunakannya budaya sebagai pendekatan dalam pembelajaran matematika[6]. Etnomatematika memiliki pengertian yang lebih luas dari hanya sekedar etno (etnis) atau suku. Jika ditinjau dari sudut pandang riset maka etnomatematika didefinisikan sebagai antropologi budaya (cultural anropology of mathematics) dari matematika dan pendidikan matematika[7].

Gagasan untuk memanfaatkan unsur sosial budaya ke dalam pembelajaran matematika telah diprakarsai sejak tahun 1977 oleh seorang matematikawan Brazil, Ubiratan D'Ambrosio. Ia mengistilahkan matematika yang dipraktekkan oleh kelompok budaya seperti kelompok perkotaan dan pedesaan, kelompok buruh, anak-anak dari kelompok usia tertentu, atau masyarat adat sebagai etnomatematika. Matang menyatakan integrasi etnomatematika ke dalam kurikulum matematika formal adalah salah satu cara untuk mengatasi kesulitan siswa belajar matematika. D'Ambrosio mengungkapkan bahwa etnomatematika melengkapi upaya dari guru dan siswa dalam pembelajaran matematika sekolah formal dalam memberikan makna kontekstual yang relevan [6]. Pemaanfaat budaya ke dalam pembelajaran matematika sangatlah penting karena dapat menambah wawasan peserta didik mengenai budaya yang dipelajarinya.

Begitu banyak keberagaman budaya di Indonesia tetapi dalam penelitian ini penulis menggunakan Rumah Adat Lampung karena kita tinggal di daerah Lampung hal ini bertujuan agar peserta didik dapat mengenal dan dapat memahami akan budayanya terutama budaya Lampung.

Berdasarkan hasil wawancara yang dilakukan pada tanggal 9 Maret 2017 dengan salah satu guru bidang studi matematika di SMP Negeri 1 Limau yaitu Fitra Hariyadi, S.Pd diperoleh informasi bahwa pada saat proses pembelajaran bangun ruang sisi datar yaitu dengan cara guru menjelaskan materi pembelajaran secara konvensional dan media yang digunakan masih terlalu minim yaitu replika bangun ruang, sementara peserta didik membutuhkan media yang lebih konkret. Hal ini tentunya untuk 
mempermudah pemahaman peserta didik terhadap materi bangun ruang sisi datar yang mereka anggap sukar. Selain itu di SMP Negeri 1 Limau belum ada media pembelajaran matematika yang mengaitkan dengan budaya.

Hasil wawancara yang dilakukan di Madrasah Tsanawiyah Masyariqul Anwar yang beralamatkan di Jl. Khairil Anwar No 5/05 Durian Payung, Tj. Karang Pusat Kota Bandar Lampung dengan guru bidang study matematika kelas VIII yaitu Winarni, S.Pd didapatkan informasi bahwa di Madrasah Tsanawiyah Masyariqul Anwar belum ada media pembelajaran yang mengaitkan matematika dengan budaya khususnya pada materi bangun ruang sisi datar. Pada saat proses belajar megajar masih menggunakan buku paket sebagai bahan dalam proses belajar mengajar, selain buku paket media pembelajaran yang digunakan adalah powert point. Powert point yang digunakanpun kurang maksimal karena terkadang peserta didik menjadi bosan. Sehingga peserta didik, membutuhkan media pembelajaran yang lebih menarik dan lebih konkret.

Penelitian pendidikan matematika yang sudah ada umumnya lebih terfokus pada ruang kelas. Namun, terdapat temuan baruyang menunjukkan bahwa banyak pengetahuan matematika yang juga dapat diperoleh diluar sekolah, salah satunya temuan tentang etnomatematika.

Teknologi arsitektur tradisional masyarakat Lampung tidak saja dilihat sebagai bentuk, tetapi juga sebagai ruang yang terjadi karena kebutuhan, adat kebiasaan, pandangan hidup, norma, tatanan nilai. Dengan pemahaman demikian, arsitektur tradisional akan banyak menggambarkan kebudayaan yang ada. Arsitektur rumah tradisional Lampung masih dapat dikatakan "hidup". Masih banyak masyarakat Lampung yang mempertahankan rumah tradisionalnya. Rumah yang secara arsitektural sesuai dengan kaidah yang diakui bersama dan dianut oleh sebagian besar masyarakat asli daerah ini sebagai tradisi turun temurun [8]. Rumah Adat Lampung sangat berperan dalam pengembangan media pembelajaran matematika karena keterkaitan Rumah Adat Lampung dengan materi bangun ruang sisi datar yaitu kubus, balok, prisma segitiga, dan limas segiempat sangatlah tepat. Kebik dan pondasi rumah berbentuk kubus, tepas, ijan, tiang penyangga, tungku berbentuk balok, dan pada atap rumah berbentuk prisma segitiga dan ada juga atap rumah yang berbentuk limas segiempat.

AdobeFlash merupakan gabugan konsep pembelajaran dengan teknologi audio visual yang mampu menghasilkan fitur-fitur baru yang dapat dimanfaatkan dalam pembelajaran. fitur-fitur yang ada dalam Adobe Flash mampu mendesain animasi-animasi yang lebih menarik, tidak monoton dan memudahkan menyampaikan materi [9]. Dalam penerapannya, Adobe Flash dapat digunakan untuk membuat media pembelajaran interaktif secara efektif dan efisien sertamudahdiakses oleh siswa,sebab dunia pendidikan dituntutuntukselalu berkembangsecara cepatmengikuti perkembangan ilmu dan teknologi. Kelebihan kemudahan pengoperasian dalam penggunaan media pembelajaran berbasis Adobe Flash yaitu dengan penggunan fungsi tombol-tombol interaktif yang memudahkan kegiatan belajar mengajar sesuai yang diinginkan.

Berdasarkan rumusan masalah di atas maka penelitian ini bertujuan untuk mengetahui kelayakan media pembelajaran matematika berbantu Adobe Flash melalui etnomatematika pada Rumah Adat Lampung dan untuk mengetahui respon peserta didik terhadap media pembelajaran matematika berbantu Adobe Flash melalui etnomatematika pada Rumah Adat Lampung.

Hamalik dalam Trisno mengatakan pembelajaran adalah suatu kombinasi yang tersusun meliputi unsur- unsur manusiawi, material, fasilitas, perlengkapan, dan prosedur yang saling mempengaruhi mencapai tujuan pembelajaran. Dimyati dan Mujiono dalam Trisno mengatakan pembelajaran merupakan proses yang diselenggarakan oleh guru untuk membelanjakan siswa dalam belajar, bagaimana memperoleh, memproses pengetahuan, keterampilan sertasikap [10]. 
Matematika merupakansalah satu mata pelajaran yang wajib dilaksanakan pada setiap jenjang pendidikan mulai dari sekolah dasar sampai perguruan tinggi. Maka dari itu, hal tersebut menunjukkan bahwa matematika memiliki peranan penting bagi dunia pendidikan dan perkembangan teknologi. Bertolak belakang dengan peran penting matematika, faktanya masih banyak siswa yang menganggap matematika adalah pelajaran yang sulit. Hal ini diduga terjadi karena matematika bersifat abstrak dan harus memahami konsep sehingga siswa merasa jenuh dan bosan dalam belajar matematika [11].

Media pembelajaran adalah sarana yang dapat digunakan sebagai perantara yang berguna untuk meningkatkan efektifitas dan efisiensi dalam pembelajaran di sekolah yang betujuan untuk meningkatkan mutu Pendidikan [12]. Media pembelajaran elektronik yang dapat digunakan saat ini salah satunya berbantu Adobe Flash. Adobe Flash adalah Program aplikasi multimedia adalah sebuah program komputer yang memanfaatkan fasilitas yang ada pada komputer seperti video dan audio yang digunakan untuk visualisasi. Contoh program aplikasi yang dapat ditemui dalam kehidupan sehari-hari adalah program permainan (game), gambar, film dan music [13].

\section{METODE PENELITIAN}

Metode penelitian dalam penelitian ini adalah penelitian dan pengembangan (Research and Development). Research and Development merupakan suatu proses atau langkah-langkah untuk mengembangkan suatu produk baru atau menyempurnakan produk yang sudah ada [14]. Tujuan dari penelitian ini adalah untuk mengetahui kelayakan dan respon peserta didik terhadap media pembelajaran matematika berbantu Adobe Flash melalui etnomatematika pada Rumah Adat Lampung.

Langkah-langkah penelitian dan pengembangan dalam penggunaan metode Research and Develompent dalam penelitian ini hingga tujuh langkah yaitu 1) Potensi dan Masalah, 2) Pengumpulan Data, 3) Desain Produk, 4) Validasi Desain, 5) Revisi Desain, 6) Uji Coba Produk, dan 7) Revisi Produk, karena sampai tujuh langkah penelitian sudah dapat menjawab rumusan masalah.

Subjek penelitian dalam penelitian ini adalah peserta didik kelas VIII di MTs Masyariqul Anwar Bandar Lampung dan di SMP Negeri 1 Limau Tanggamus tahun ajaran 2017/2018 yang dipilih secara random berdasarkam kemampuan di dalam kelas, materi yang digunakan adalah bangun ruang sisi datar yaitu kubus, balok, prisma segitiga dan limas segiempat.

Instrument penelitian yang digunakan berupa pedoman wawancara sebagai acuan dalam melakukan wawancara kepada guru yang disusun untuk mengetahui media pembelajaran seperti apa yang sesuai dengan kebutuhan peserta didik dan berfungsi untuk memberi masukan dalam pengembangan media pembelajaran matematika berbantu Adobe Flashpada Rumah Adat Lampung. Instrument ahli materi, ahli bahasa, ahli bahasa, dan ahli budaya yang digunakan berupa angket validasi untuk mengetahui kelayakan media pembelajaran yang dikembangkan. Serta instrument uji coba produk oleh peserta untuk mengetahui respon pesrta didik terhadap media pembelajaran yang dikembangkan, instrument yang digunakan berupa angket respon peserta didik berupa pernyataan.

Teknik analisis data pada penelitian ini menggunakan teknik analisis deskriptif kualitatif yang memaparkan hasil pengembangan produk yang berupa media pembelajaran matematika berbantu Adobe Flash melalui Etnomatematika pada Rumah Adat Lampung. Data yang diperoleh melalui instrumen uji coba produk dianalisis dengan menggunakan statistik deskriptif kualitatif. Analisis ini dimaksud untuk menggambarkan karakteristik data pada masing-masing variabel. Tahapan ini akan dilakukan perhitungan yang telah ditentukan. Instrumen yang digunakan memiliki 4 jawaban, yaitu Sangat Baik (SB) diberi skor 4, Baik (B) skor 3, Cukup (C) skor 2, dan Kurang (K) skor 1. Sehingga skor penilaian total dapat dicari dengan menggunakan rumus sebagai berikut (Rusmela, 2016) 
Numerical: Jurnal Matematika danPendidikan Matematika, Vol. 2 No. 2 Desember 2018, 125-138 Resty Khairina Vevi M.P, Dona Dinda Pratiwi, Mohammad Muhassin

$$
\bar{x}=\frac{\sum_{i=1}^{n} x_{i}}{n}
$$

Dengan

$$
x_{i}=\frac{\text { Jumlah Skor }}{\text { Skor maks }} \times 4
$$

\section{HASIL DAN PEMBAHASAN}

\section{Produk Media Pembelajaran}

Media pembelajaran yang dikembangkan dalam penelitian ini berupa media pembelajaran matematika berbantu Adobe Flash melalui etnomatematika pada Rumah Adat Lampung. Media pembelajaran berupa software berisi standar kompetensi dan kompetensi inti, materi bangun ruang sisi datar yang berkaitan dengan etnomatematika pada Rumah Adat Lampung, contoh-contoh soal, soal pemantapan, latihan soal, dan soal-soal ujian nasional pada materi bangun ruang sisi datar.

Proses pembuatan media pembelajaran yaitu:

a. Mengumpulkan bahan-bahan seperti materi, contoh-contoh soal, gambar-gambar Rumah Adat Lampung dan animasi.

b. Editing yaitu pembuatan media pembelajaran berbantu aplikasi Adobe Flash

Media pembelajaran melaului etnomatematika pada Rumah Adat Lampung untuk kelas VIII pada pokok bahasan materi bangun ruang sisi datar bertujuan untuk memudahkan peserta didik dalam visualisasi

\section{Validasi Desain}

\section{a. Hasil Validasi Ahli Materi}

Validasi ahli materi bertujuan untuk menguji kelengkapan materi, kebenaran materi dan sistematika materi. Hasil data validasi materi pada tahap 1dapat dilihat pada gambar 1.

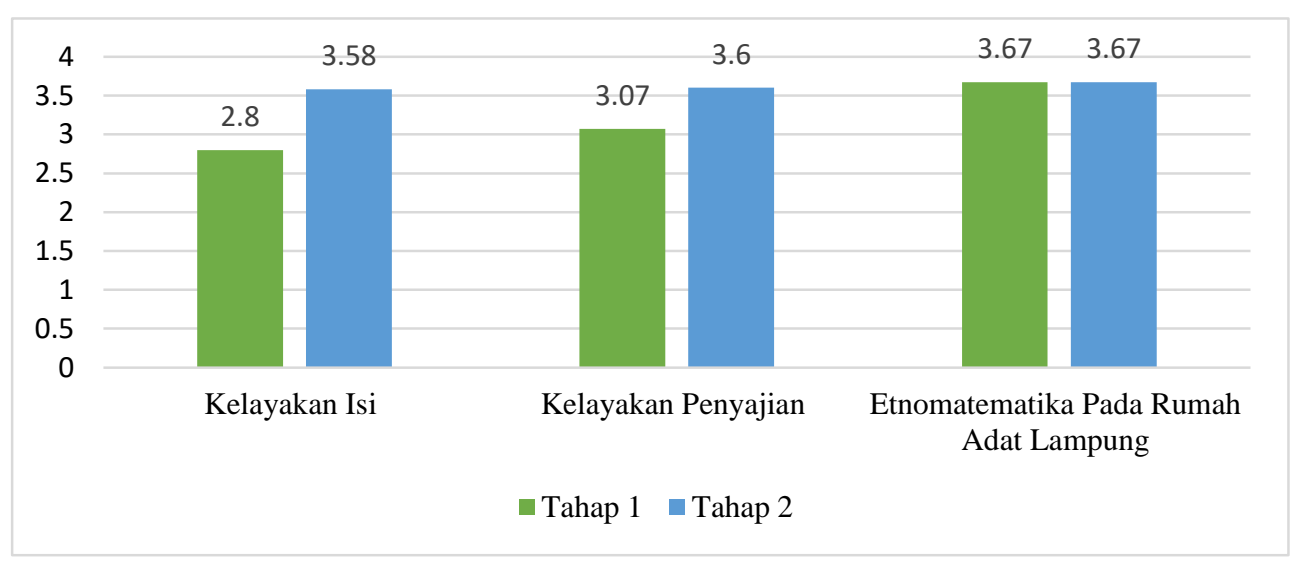

Gambar 1. Grafik Perbandingan Hasil Validasi Ahli Materi Tahap 1 dan Tahap 2

Hasil validasi tahap 1 oleh ahli materi dari 3 orang validator dapat diketahui bahwa validasi ahli materi memperoleh nilai sebagai berikut: pada aspek kelayakan isi diperoleh nilai rata-rata sebesar 2,80 dengan kriteria "cukup valid". Aspek kelayakan penyajian diperoleh nilai rata-rata sebesar 3,07 dengan kriteria "cukup valid" dan pada aspek Etnomatematika Pada Rumah Adat Lampung diperoleh nilai rata-rata sebesar 3,67 dengan kriteria "valid". Hasil validasi tahap 2 oleh ahli materi dari 3 validator dapat diketahui bahwa validasi ahli materi memperoleh nilai sebagai berikut: pada aspek kelayakan isi diperoleh nilai rata-rata sebesar 3,58 dengan kriteria "valid". 
Aspek kelayakan penyajian diperoleh nilai rata-rata sebesar 3,60 dengan kriteria "valid" dan pada aspek etnomatematika pada Rumah Adat Lampung diperoleh nilai rata-rata sebesar 3,67 dengan kriteria "valid". Dari gambargrafik perbandingan hasil ahli materi tahap 1 dan tahap 2 terlihat bahwa, terjadi peningkatan yang sangat signifikan dari tahap 1 ke tahap 2, baik pada aspek kelayakan isi dan pada aspek kelayakan penyajian kecuali pada aspek etnomatematika tidak mengalami kenaikan.

\section{b. Hasil Validasi Ahli Media}

Validasi ahli media bertujuan untuk menguji aspek tampilan software dan aspek kelayakan Software media pembelajaran matematika berbantu Adobe Flash melalui Etnomatematika pada Rumah Adat Lampung. Hasil analisis data validasi ahli media dapat dilihat pada gambar 2.

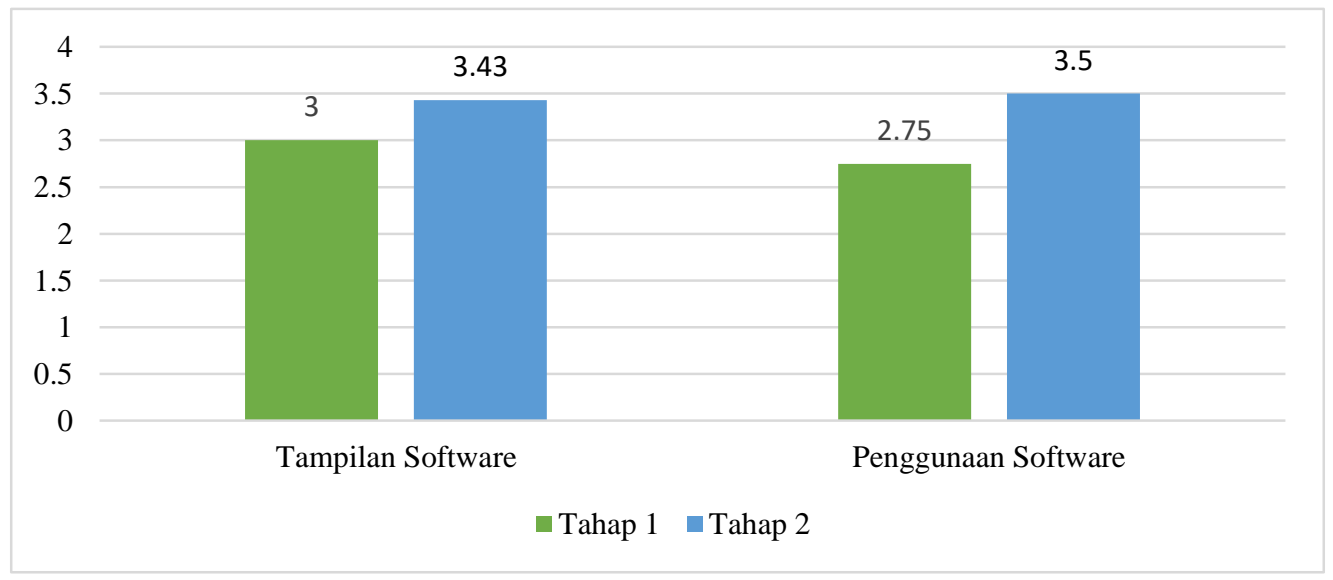

Gambar 2. Grafik Perbandinagan Hasil Validasi Ahli Media Tahap 1 dan Tahap 2

Hasil validasi oleh ahli media tahap 1diperoleh hasil penilaian bahwa pada indikator tampilan software diperoleh nilai rata-rata sebesar 3,0 dengan kriteria "cukup Valid" dan pada indikator penggunaan software diperoleh nilai rata-rata sebesar 2,75 dengan kriteria "cukup valid". Hasil validasi oleh ahli media tahap 2 diperoleh hasil penilaian bahwa pada indikator tampilan software diperoleh nilai rata-rata sebesar 3,43 dengan kriteria "valid" dan pada indikator penggunaan software diperoleh nilai rata-rata sebesar 3,5 dengan kriteria "valid". Berdasarkan gambar 2 grafik perbandingan hasil validasi ahli media tahap 1 dan tahap 2 sudah menunjukkan peningkatan yang cukup signifikan, baik pada aspek tampilan software dan aspek penggunaan software.

\section{c. Hasil Validasi Ahli Bahasa}

Validasi ahli bahasa bertujuan untuk menguji kebahasaan media pembelajaran matematika berbantu Adobe Flash melalui Etnomatematika pada Rumah Adat Lampung. Hasil analisis data validasi ahli bahasa dapat dilihat pada gambar 3 . 


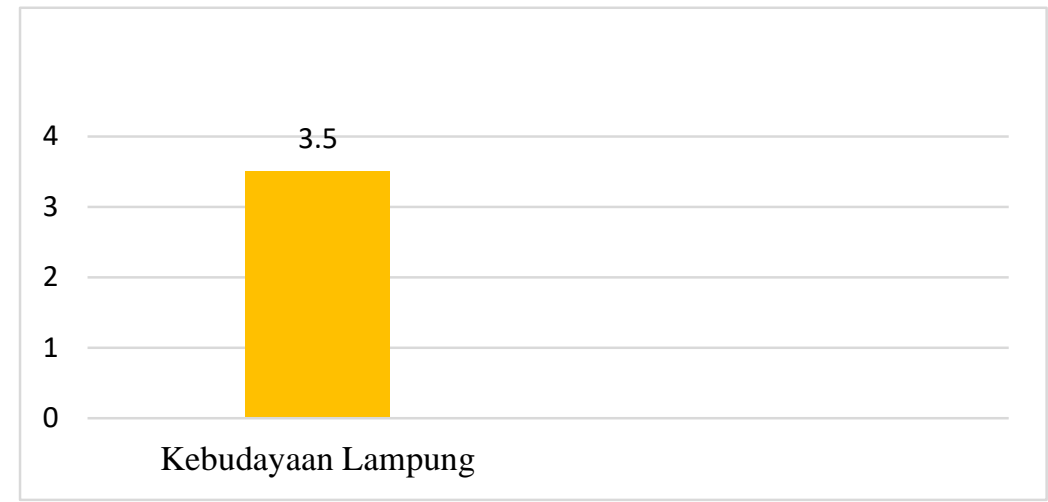

Gambar 3. Grafik Perbandingan Validasi Ahli Bahasa Tahap 1 dan Tahap 2

Hasil validasi tahap 1 oleh ahli bahasa pada gambar 3 diperoleh hasil penilaian yang terdiri dari 1 aspek yaitu aspek kebahasaan. Pada aspek kebahasaan diperoleh nilai rata-rata sebesar 3,22 dengan kriteria "cukup valid". Hasil validasi oleh ahli bahasa menunjukkan hasil penilaian bahwa pada aspek kebahasaan diperoleh nilai rata-rata sebesar 3,67dengan kriteria "valid".

\section{d. Hasil Validasi Budaya}

Validasi ahli budaya bertujuan untuk menguji kebudayaan pada media pembelajaran matematika berbantu Adobe Flash melalui Etnomatematika pada Rumah Adat Lampung. Hasil analisis data validasi ahli budaya dapat dilihat pada gambar 4.

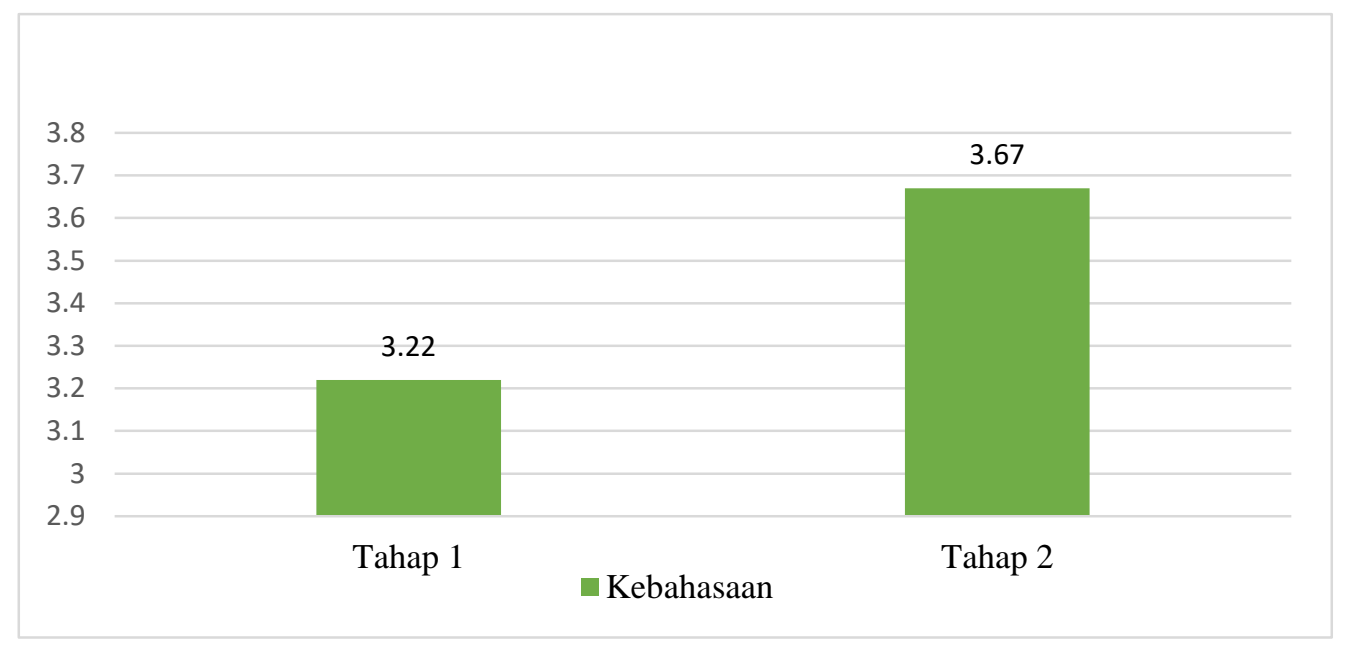

Gambar 4. Grafik Hasil Validasi Ahli Budaya

Hasil validasi oleh ahli budaya menunjukkan hasil penilaian bahwa pada kebudayaan Lampung diperoleh nilai sebesar 3,5 dengan kriteria "valid". Terlihat grafik hasil validasi ahli budaya dengan nilai aspek kebudayaan Lampung memperoleh kriteria "valid" maka etnomatematika sudah layak dan tidak dilakukan perbaikan lagi.

Berdasarkan hasil validasi ahli materi, ahli media, ahli bahasa dan ahli budaya di atas terlihat bahwa bahan ajar yang dikembangkan sudah valid sehingga dapat dilanjutkan ketahap selanjutnya. 
Numerical: Jurnal Matematika danPendidikan Matematika, Vol. 2 No. 2 Desember 2018, 125-138

Resty Khairina Vevi M.P, Dona Dinda Pratiwi, Mohammad Muhassin

\section{Revisi Desain}

Setelah desain produk divalidasi melalui penilaian ahli materi, ahli media, ahli bahasa, dan ahli budaya peneliti melakukan revisi terhadap desain produk yang dikembangkan berdasarkan saran dan masukan ahli tersebut.

a. Revisi Desain Ahli Materi

1) Perbaiki rumus matematika yang digunakan.

2) Perbaiki unsur-unsur kubus.

3) Tambahkan soal ujian nasional.

4) Tambahkan kunci jawaban pada latihan soal.

b. Revisi Desain Ahli Media

1) Buat tampilan lebih menarik.

2) Perbaiki tampilan layar dengan gambar atau background dengan warna yang lebih berfariasi atau terang.

3) Tambahkan menu pada setiap unsur bangun untuk meminimalisir waktu ke materi selanjutnya.

4) Tambahkan menu pause pada materi.

c. Revisi Desain Ahli Bahasa

1) Behani penulisan pangkat.

2) Benahi beberapa tanda baca yang kurang tepat.

\section{Uji Coba Produk}

Setelah produk melalui tahap validasi oleh ahli materi, ahli media, ahli bahasa, dan ahli budaya serta telah selesai diperbaiki, selanjutnya produk diuji cobakan dengan uji coba kelompok kecil dan uji coba kelompok besar dari 2 sekolah, yaitu MTs Masyariqul Anwar Bandar Lampung dan SMP Negeri 1 Limau Tanggamus. Uji coba kelompok kecil dari masing-masing sekolah terdiri dari 10 peserta didik dan uji coba kelompok besar yang terdiri dari 30 peserta dan uji coba guru yang terdiri dari 1 guru matematika di MTs Masyariqul Anwar Bandar Lampung dan 1 guru matematika di SMP Negeri 1 Limau. Adapun hasil uji coba produk sebagai berikut:

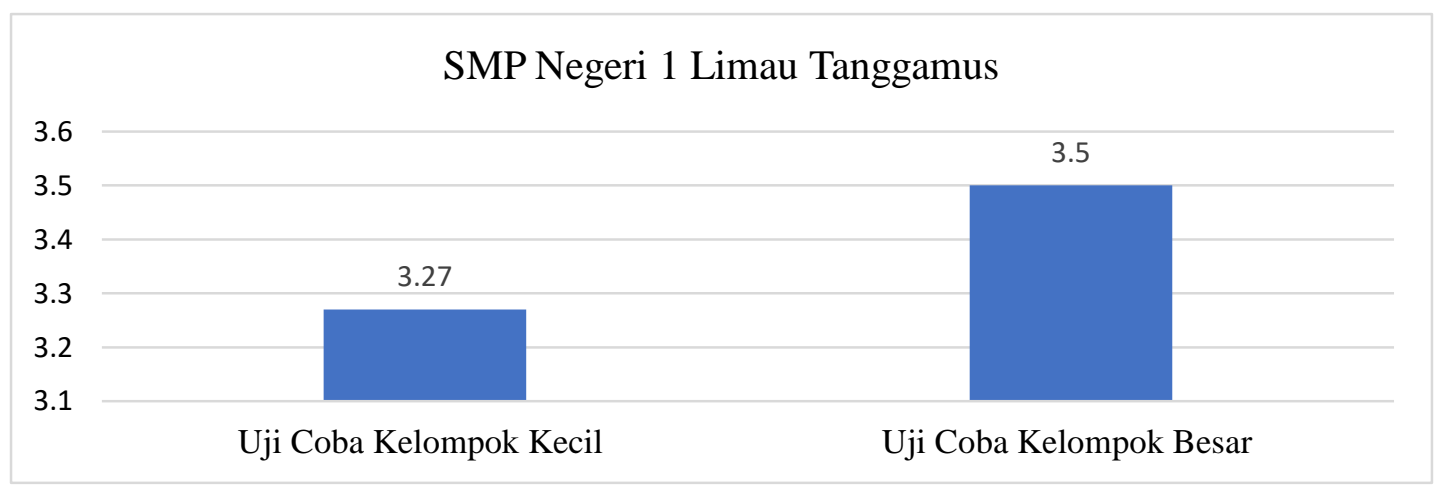

Gambar 5.

Hasil Uji Coba Produk Kelompok Kecil dan Kelompok Besar di MTs Masyariqul Anwar Bandar Lampung 
a. Uji Coba Pesera Didik

Berdasarkan grafik pada gambar 5 hasil uji coba kelompok kecil dan hasil coba kelompok besar di MTs Masyariqul Anwar Bandar Lampunguntuk uji coba kelompok kecil diperoleh ratarata 3,2 dengan kriteria interpretasi yang dicapai yaitu "menarik" dan untuk uji coba kelompok besar diperoleh nilai rata-rata 3,43 dengan kriteria interpretasi yang dicapai yaitu "sangat menarik".

Hasil uji coba kelompok kecil dan hasil coba kelompok besar di SMP Negeri 1 Limau tanggamus,untuk uji coba kelompok kecil diperoleh rata-rata 3,27 dengan kriteria interpretasi yang dicapai yaitu "sangat menarik" dan untuk uji coba kelompok besar diperoleh nilai rata-rata 3,5 dengan kriteria interpretasi yang dicapai yaitu "sangat menarik".

Setelah dilakukan uji coba produk didua sekolah dan mendapat respon "sangat menarik", hal ini berarti media pembelajaran yang dikembangkan oleh peneliti mempunyai kriteria "sangat menarik" untuk digunakan sebagai media pembelajaran bagi peserta didik pada materi bangun ruang sisi datar untuk peserta didik kelas VIII di SMP/MTs.

b. Uji Coba Produk pada Guru

Setelah melakukan uji coba kelompok kecil dan uji coba kelompok besar, kemudian produk diuji cobakan kembali ke uji coba produk pada guru. Hasil data uji coba guru di MTs Masyariqul Anwar Bandar Lampung terhadap media pembelajaran dapat dilihat pada Tabel 1.

Tabel 1. Hasil Uji Coba Guru di MTs Masyariqul Anwar Bandar Lampung

\begin{tabular}{|c|c|c|c|}
\hline No. & Indikator Penilaian & Analisis & Validator \\
\hline \multirow{4}{*}{1.} & \multirow{4}{*}{ Kualitas Isi } & $\sum$ Skor & 17 \\
\hline & & $x_{i}$ & 3,4 \\
\hline & & $\bar{x}$ & 3,4 \\
\hline & & Kriteria & Sangat Baik \\
\hline \multirow{4}{*}{2.} & \multirow{4}{*}{ Keterlaksanaan } & $\sum$ Skor & 11 \\
\hline & & $x_{i}$ & 3,67 \\
\hline & & $\bar{x}$ & 3,67 \\
\hline & & Kriteria & Sangat Baik \\
\hline
\end{tabular}

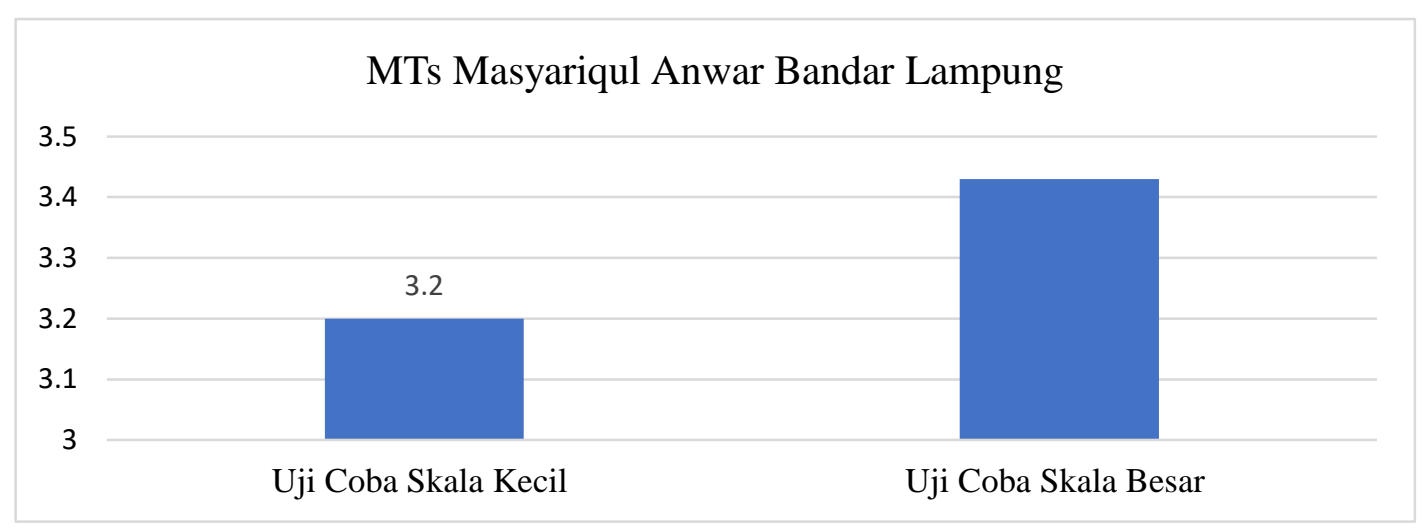

Hasil uji coba guru di MTs Masyariqul Anwar Bandar pada aspek kualitas isi diperoleh nilai rata-rata sebesar 3,4 dengan kriteria "sangat baik" dan Aspek keterlaksanaan diperoleh nilai ratarata sebesar 3,67 dengan kriteria "sangat baik". Hal ini menunjukkan media pembelajaran yang dikembangkan oleh peneliti mempunyai kriteriasangat baik untuk digunakan sebagai alat bantu dalam kegiatan belajar mengajar pada materi bangun ruang sisi datar untuk kelas VIII SMP/MTs 
semester genap. Hasil uji coba produk pada guru juga dilakukan di SMP Negeri 1 Limau Tanggamus dapat dilihat pada tabel 2.

Tabel 2. Hasil Uji Coba Guru di MTs SMP Negeri 1 Limau Tanggamus

\begin{tabular}{|c|c|c|c|}
\hline No. & $\begin{array}{l}\text { Indikator } \\
\text { Penilaian }\end{array}$ & Analisis & Validator \\
\hline \multirow{4}{*}{1.} & \multirow{4}{*}{ Kualitas Isi } & $\sum$ Skor & 17 \\
\hline & & $x_{i}$ & 3,4 \\
\hline & & $\bar{x}$ & 3,4 \\
\hline & & Kriteria & Sangat Baik \\
\hline \multirow{4}{*}{2.} & \multirow{4}{*}{ Keterlaksanaan } & $\sum$ Skor & 10 \\
\hline & & $x_{i}$ & 3,33 \\
\hline & & $\bar{x}$ & 3,33 \\
\hline & & Kriteria & Sangat Baik \\
\hline
\end{tabular}

Hasil uji coa guru di SMP Negeri 1 Limau Tanggamus memperoleh nilai sebagai berikut: pada aspek kualitas isi diperoleh nilai rata-rata sebesar 3,4 dengan kriteria "sangat baik" dan keterlaksanaan diperoleh nilai rata-rata sebesar 3,33 dengan kriteria "sangat baik", sehingga media pembelajaran layak untuk digunakan. Hal ini menunjukkan media pembelajaran yang dikembangkan oleh peneliti mempunyai kriteriasangat baik untuk digunakan sebagai alat bantu dalam kegiatan belajar mengajar pada materi bangun ruang sisi datar untuk kelas VIII SMP/MTs semester genap.

\section{Kajian Produk Akhir}

Media pembelajaran yang dikembangkan adalah sebaga fasilitator peserta didik dalam belajar. Tujuan dari pengembangan ini adalah menghasilkan media pembelajaran matematika berbantu Adobe Flash melalui Etnomatematika pada Rumah Adat Lampung. Prosedur penelittian dan pengambangan Research and Development (R\&D) dan dengan model pengembangan Borg and Gall yang dimodifikasi oleh Sugiyono hanya dibatasi sampai tujuh langkah penelitian dan pengembangan. Alasan peneliti membatasi hanya sampai tujuh langkah penelitian dan pengembangan karena sampai pada tahap tujuh sudah dapat menjawab hasil penelitian. Sistematika media pembelajaran yang disajikan secara berurut yaitu: indikator, materi yang terdiri dari kubus, balok, prisma segitiga, limas segiempat serta contoh soal dan soal pemantapan, latihan soal dan soal ujian nasional dan daftar pustaka.

Penyusunan materi bangun ruang sisi datar yaitu kubus, balok, prisma segitga dan limas segiempat, contoh soal, pemantapan soal, latihan soal dan soal ujian nasional tahun 2015/2016 materi bangun ruang sisi datar, soal ujian nasional 2016/2017 bangun ruang sisi datar, dalam media pembelajaran disusun dengan berbantu Adobe Flash melalui etnomatematika pada Rumah Adat Lampung.

Media pembelajaran matematika berbantu Adobe Flash melalui etnomatematika pada Rumah Adat Lampung secara keseluruhan telah melalui tahapan-tahapan validasi oleh para ahli materi, ahli media, ahli bahasa, dan ahli budaya, selain itu juga telah dilakukan perbaikan-perbaikan sesuai saran para validator dan menghasilkan kriteria valid sehingga media pembelajaran matematika yang dikembangkan oleh peneliti layak untuk digunakan dalam kegiatan pembelajaran. Penyususnan Materi, contoh soal, pemantapan soal, dan latihan soal.

Pada media pembelajaran matematika berbantu Adobe melalui etnomatematika pada Rumah Adat Lampung terdapat bagian-bagian rumah adat lampung yang dapat dikaitkan dengan materi bangun ruang sisi datar yaitu pada ijan, tepas, tiang penyangga rumah, dan tunggu dapat membentu 
balok. Bentuk kubus terdapat pada kebik dan pondasi tiang penyangga. Atap rumah pada rumah adat lampung memiliki 2 tipe yaitu atap rumah yang berbentuk prisma segitiga dan atap rumah berbentuk limas segiempat.

Media pembelajaran melalui etnomatematika pada Rumah Adat Lampung dikatakan valid oleh para validator karena pemilihan etnomatematika pada Rumah Adat Lampung yang dikaitkan dengan materi bangun ruang sisi datar sudah tepat dan menambah wawasan peserta didik mengenai budaya lampung yaitu Rumah Adat Lampung. Selain etnomatematika, Adobe Flash juga berperan penting dalam pembuatan media pembelajaran karena mempunyai fitur yang lebih lengkap dibanding software jenis lain dan dari segi pengoperasian Adobe Flash juga sangat mudah sehingga karena terdapat tombola tau menu sederhana yang mudah dioperasikan serta tidak menyulitkan ketika proses belajar mengajar. Jadi penggunaan software Adobe flash sendiri merupakan pilihan yang tepat dalam membuat suatu media pembelajaran.

Berdasarkan hasil yang telah diperoleh pada uji coba skala kecil dan uji coba lapangan yang diuji cobakan kepada peserta didik didua sekolah yaitu MTs Mayariqul Anwar Bandar Lampung terhadap media pembelajaran yang dikembangkan menghasilkan media pembelajaran dalam kriteria interpretasi sangat menarik. Kemenarikan dari media pembelajaran disebabkan peran etnomatematika pada Rumah Adat Lampung yang digunakan serta penggunaan aplikasi Adobe Flash didalam membuat media pembelajaran tersebut. Etnomatematika pada Rumah Adat Lampung berperan didalam penyusunan materi yang terdapat dalam media pembelajaran yang mana materi dikaitkan dengan kehidupan seharihari sehingga peserta didik akan lebih mudah dalam memahami materi yang sedang dipelajarinya dan menambah wawasan peserta didik mengenai budaya Lampung yaitu Rumah Adat Lampung. Sedangkan aplikasi Adobe Flash berperan didalam pembuatan media pembelajaran, yang mana aplikasi Adobe Flash didalam pembuatan media pembelajaran tesebut mendukung penambahan gambar-gambar dan suara sehingga peserta didik saat belajar dengan menggunakan media pembelajaran tersebut tidak menjadi jenuh ataupun bosan.

\section{Kelebihan dan Kekurangan Media Pembelajaran yang dikembangkan}

Produk pengembangan ini memiliki beberapa kelebihan dan kekurangan sebagai berikut ini:

a. Kelebihan Produk Hasil Pengembangan

Kelebihan media pembelajaran matematika berbantu Adobe Flash melalui Etnomatematika pada Rumah Adat Lampung antara lain:

1) Media pembelajaran yang dikembangkan memuat materi bangun ruang sisi datar yang dikaitkan dengan Etnomatematika Pada Rumah Adat Lampung sehingga menambah wawasan peserta didik mengenai budaya Lampung.

2) Media pembelajaran yang dikembangkan berupa aplikasi/software sehingga lebihfleksibel sehingga mudah dibawa kemana mana.

3) Media pembelajaran yang dikembangkan dilengkapi dengan latihan soal untuk mengetahui tingkat penguasaan materi dan pencapaian kompetensi dasar setiap materi.

b. Kekurangan Produk Hasil Pengembangan

Kekurangan media pembelajaran matematika berbantu Adobe Flash melalui

Etnomatematika pada Rumah Adat Lampung antara lain:

1) Media pembelajaran yang dikembangkan berupa aplikasi sehingga hanya dapat dioperasikan menggunkaan laptop atau komputer.

2) Materi yang terdapat pada media pembelajaran hanya sebatas materi bangun ruang sisi datar kelas VIII. 
3) Etnomatematika pada Rumah Adat Lampung yang dapat diaplikasikan ke dalam materi bangun ruang sisi datar hanya sebagian bangunan yaitu ijan, kamar tidur, tepas, tiang penyangga rumah, atap rumah berbentuk prisma segitiga, dan atap rumah berbantuk limas segiempat.

\section{SIMPULAN DAN SARAN}

Berdasarkan penelitian dan pembahasan yang telah dipaparkan dapat disimpulkan bahwa pengembangan media pembelajaran berupa media pembelajaran berbasis etnomatematika pada Rumah Adat Lampung pada pokok bahasan bangun ruang sisi datar adalah layak dan menarik untuk digunakan bagi peserta didik.

Beberapa saran yang dapat diberikan untuk pengembangan media pembelajaran matematika berbantu Adobe Flash melalui Etnomatematika pada Rumah Adat Lampung adalah media pembelajaran hanya menyajikan materi bangun ruang sisi datar SMP/MTs kelas VIII semester genap, sehingga diharapkan untuk media pembelajaran selanjutnya dapat dikembangkan media pembelajaran matematika melalui Etnomatematika pada Rumah Adat Lampung dengan materi yang lebih luas. Selain itu, media pembelajaran matematika melalui Etnomatematika pada Rumah Adat Lampung masih banyak kekurangan dalam pembuatan atau pengembangannya sehingga pengembangan media pembelajaran selanjutnya dapat dikembangkan media pembelajaran matematika berbantu Adobe Flash melalui Etnomatematika pada Rumah Adat Lampung yang lebih baik, agar dapat menambah pengetahuan peserta didik terhadap kebudayaan Lampung dan menumbuhkan minat peserta didik dalam mengikuti pembelajaran matematika pada materi bangun ruang sisi datar.

\section{DAFTAR PUSTAKA}

[1] R. Wa. Y. Putra and R. Anggraini, "Pengembangan Bahan Ajar Materi Trigonometri Berbantuan Software iMind Map pada Siswa SMA,” vol. 7, no. 1, pp. 39-47, 2016.

[2] R. D. Purwanti, D. D. Pratiwi, and A. Rinaldi, "Pengaruh Pembelajaran Berbatuan Geogebra terhadap Pemahaman Konsep Matematis ditinjau dari Gaya Kognitif," vol. 7, no. 1, pp. 115-122, 2016.

[3] B. S. Anggoro, "Pengembangan Modul Matematika Dengan Strategi Problem Solving untuk Mengukur Tingkat Kemampuan Berpikir Kreatif Matematis Siswa," vol. 6, no. 2, pp. 121-129, 2015.

[4] TIMMS, 2017.

[5] A. Arsyad, Media Pembelajaran. Rajawali Pers, 2016.

[6] C. S. Ubayanti, H. Lumbantobin, and M. M. H. Manurung, "Eksplorasi Etnomatematika Pada Sero (SET NET): Budaya Ubayanti, dkk Masyarakat Kokas Fakfak Papua Barat," vol. 2, 2016.

[7] E. Tandililing, "Dengan Pendekatan Etnomatematika Berbasis Budaya Lokal Sebagai Upaya untuk Meningkatkan,” no. 1992, pp. 978-979, 2013.

[8] A. Djasual and D. Hartawan, Rumah Tradisisonal Lampung. 2002.

[9] G. Marianda, A. Johar, and E. Risdianto, "Rancang Bangun Media Pembelajaran Berbasis Multimedia Interaktif Konsep Gaya Pada Mata Pelajaran Fisika SMP Kelas VIII,” vol. 2, no. 2, pp. 112-120, 2014. 
[10] H. Trisno and Ba. E. Purnama, "Pembuatan Media Pembelajaran Aksara Jawa pada Sekolah Dasar,” vol. 4, no. 1, pp. 59-65, 2013.

[11] M. Maharani, N. Supriadi, and R. Widyastuti, "Media Pembelajaran Matematika Berasis Kartun Untuk Menurunkan Kecemasan Siswa," vol. 1, no. 1, pp. 101-106, 2018.

[12] R. Masykur, Novrizal, and M. Syazali, "Pengembangan Media Pembelajaran Matematika Dengan Macromedia Flash,” vol. 8, no. 2, pp. 177-185, 2017.

[13] A. S. Sadiman, R. Rahardjo, A. Haryono, and Rahardjito, Media Pendidikan, 1 Cet 16. 2012.

[14] W. Octavianty and P. W. Rusimamto, "Pengembangan Media Pembelajaran Imindmap Menggunakan Metode Mind Mapping Terhadap Hasil Belajar Siswa Pada Kompetensi Dasar Menerapkan Sistem Konversi Bilangan Pada Rangkaian Logika di SMK Negeri 2 Surabaya,” pp. 869-873, 2015. 
Numerical: Jurnal Matematika danPendidikan Matematika, Vol. 2 No. 2 Desember 2018, 125-138

Resty Khairina Vevi M.P, Dona Dinda Pratiwi, Mohammad Muhassin

[Halaman ini sengaja dikosongkan] 